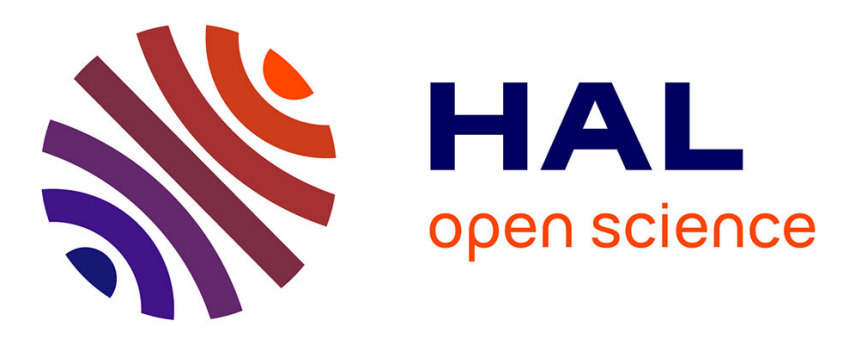

\title{
Targeting of single stranded oligonucleotides through metal-induced cyclization of short complementary strands
}

Fabrice Freville, Tristan Richard, Katell Bathany, Serge Moreau

\section{- To cite this version:}

Fabrice Freville, Tristan Richard, Katell Bathany, Serge Moreau. Targeting of single stranded oligonucleotides through metal-induced cyclization of short complementary strands: Targeting of single stranded oligonucleotides. Helvetica Chimica Acta, 2006, 89 (12), pp.2958-2974. 10.1002/hlca.200690265 . inserm-00107329

\section{HAL Id: inserm-00107329 https://www.hal.inserm.fr/inserm-00107329}

Submitted on 11 May 2010

HAL is a multi-disciplinary open access archive for the deposit and dissemination of scientific research documents, whether they are published or not. The documents may come from teaching and research institutions in France or abroad, or from public or private research centers.
L'archive ouverte pluridisciplinaire HAL, est destinée au dépôt et à la diffusion de documents scientifiques de niveau recherche, publiés ou non, émanant des établissements d'enseignement et de recherche français ou étrangers, des laboratoires publics ou privés. 


\title{
Targeting of single stranded oligonucleotides through metal-
}

\section{induced cyclization of short complementary strands}

\author{
by Fabrice Freville ${ }^{\mathrm{a}}$, Tristan Richard ${ }^{\mathrm{a}}$, Katell Bathany ${ }^{\mathrm{b}}$ and Serge Moreau ${ }^{{ }^{\mathrm{a}}}$ \\ aNSERM U386, Bordeaux, Université Victor Segalen Bordeaux2, 146 rue Léo Saignat F- \\ 33076 Bordeaux Cedex, France
}

${ }^{\mathrm{b}}$ Institut Européen de Chimie et de Biologie (IECB), 2 rue Robert Escarpit, 33607 Pessac Cedex, France

serge.moreau@bordeaux.inserm.fr 


\begin{abstract}
A new strategy to cyclize a short synthetic oligonucleotide on a DNA or a RNA target strand is described. The approach is based on metal-templated cyclization of short synthetic oligonucleotides conjugated with two chelating 2,2':6',2"-terpyridine moieties at their $3^{\prime}$ and $5^{\prime}$ ends. Cyclization following metal addition $\left(\mathrm{Zn}^{2+}, \mathrm{Fe}^{2+}\right)$ was demonstrated by means of thermal denaturation experiments, MALDI-Q-TOF6MS and gel electrophoresis (PAGE). 1D- and 2DNMR experiments were performed to analyse the association of complementary strands after metal-mediated cyclization. Our protocol allows the efficient circularisation of synthetic oligonucleotides. Thereby, the hybridization on a complementary strand was more efficient with a RNA target strand and a 2'-O-methyl circularized oligomer.
\end{abstract}




\section{Introduction}

RNA can form stable structures with a small number of nucleotides. Combination of various secondary structural elements can lead to tertiary structures of increasing complexity [1]. Such structures are involved in numerous regulation processes through interactions with RNA, DNA or proteins [2]. The iron-responsive element (IRE), a hairpin structure present in mRNAs coding for key proteins in the iron metabolism of vertebrate cells, is a good example [3]. Numerous examples of functional RNAs are also found in viruses, TAR RNA is the RNA sequence required for transactivation of the of the transcription of the HIV-1 genome [4]. So ligands designed to target such RNA motifs may allow the control of the metabolic processes that they mediate.

We are interested in strategies aiming at locking, through catenane formation, synthetic oligonucleotides on hairpin motifs of RNA an essential secondary structure of RNA often involved in regulation of gene expression [3]. Catenanes are intertwined polymember rings tied together $[5,6]$. Such bulky synthetic complexes on RNA hairpin may allow an efficient inhibition of the association of the natural ligands of these structures. Our first attempt in this line is developed here using modified oligonucleotides bearing terminal 2,2':6',2"'-terpyridines moieties which may lead, following addition of metal ions to the formation of a catenane structure with the targeted hairpin (Scheme 1A). Cyclic,[7] polymeric [8] and chiral assemblies [9] could be obtained utilizing the chemistry of terpyridines and metal complexes. Physiologically available ions such as zinc could be recruited to mediate such a process [10]. The high dynamic characteristics of Zn-(Tpy $)_{2}$ complexes will allow an easy closing of the ligand on a RNA hairpin [11]. We previously developed methods of conjugation of terminal terpyridine (Tpy) on synthetic oligomers and showed that metallic coordination lead to large 
increase in the stability of duplexes or short hairpins [12]. In order to evaluate the ability of terpyridine modified oligonucleotides to cyclize around the targeted strand we designed a simplified system where the target strand (DNA or RNA) is a short linear sequence allowing the formation of a 9 base pair duplex with the Tpy-modified oligomer. Such a one turn helical duplex will put the $3^{\prime}$ and 5' Tpy residues in a face-to-face conformation allowing an easy closing through metal coordination and leading to a target strand passing through the circularized Tpy oligomer (Scheme 1B). This topology is a prerequisite for the formation of the interlocked rings of a catenane structure.

The target oligomer sequences were derived from a RNA hairpin of the internal ribosomal entry site (IRES) of the hepatitis $\mathrm{C}$ virus (HCV). The apical loop of the domain IIIb of this IRES fulfil some of the above mentioned criteria. First it is involved in the IRES function by recruiting essential co-factors of translation initiation such as eIF3 [13]. Second the length of the loop (14 nt) allows the hybridization of a complementary strand leading to a one turn helical double helices.

\section{Results}

\section{Oligomers sequences.}

All strand sequences are shown in Table 1. Either DNA or RNA sequences were used as targets. The complementary strands were DNA and 2'-O-methyl oligonucleotides. Analytical data of chemically modified oligomers are reported in Table 1.

Molecular modeling and chemical synthesis.

We chose a new chemical approach we used recently to allow an easy synthesis of bisterpyridine conjugated oligonucleotides. [14] This one relies on the use of 2,4- 
dihydrobutyramide as substitute for nucleosides as shown by Dioubankova.[15] This synthon allows the introduction of various ligands or labels at both ends of oligonucleotides through phosphoramidite chemistry and the synthesis of specific solid support. To define the length of the chemical link between the Tpy moieties and the 3', 5' $\mathrm{OH}$ groups of the cyclic oligomer according to scheme 1, we built an initial duplex using an ideal A-form double-helical model. The coordination link and geometry of the terpyridines units were constrained according to coordinate data of X-ray diffraction study of iron complexes [16]. The general structure of Tpy conjugated oligomers are shown in scheme $2 \mathrm{~A}$. A representation of the optimized structure of the hybridized A -form duplex is depicted in scheme $2 \mathrm{~B}$.

\section{Melting temperature experiments.}

As a first analysis of the putative circularization of the Tpy-modified oligomer around its target, we designed various combinations of complementary strands and followed their association by UV monitored thermal denaturation experiments. Three kinds of duplexes were used: type 0 for unconjugated oligomers, type I for mono-terpyridine conjugates and II for the bis-terpyridine ones. Strands associations were studied in metal free buffer (10 mM phosphate buffer ( $\mathrm{pH} 7.0), 150 \mathrm{mM}$ sodium chloride, $200 \mu \mathrm{M}$ EDTA) and in the presence of control amounts of metal ions $\left(\mathrm{Zn}^{2+}, \mathrm{Fe}^{2+}, \mathrm{Ni}^{2+}\right)$ using the same buffer without EDTA. Added equivalents refer to the duplex concentration $(1 \mu \mathrm{M})$. The experimental data for DNA targets are reported in Table 2. Denaturation of the samples were carried out by increasing the temperature from $4{ }^{\circ} \mathrm{C}$ to $90^{\circ} \mathrm{c}$. The melting temperature was obtained through graphical methods. Tm uncertainty obtained from multiple experiments are $\pm 1^{\circ} \mathrm{C}$. A striking feature of these data are that type II duplexes exhibited a significant drop in Tm values compared to any other strand associations. Although Tm data were difficult to determine in these cases, a melting transition 
(Tm values around 10 to $20^{\circ} \mathrm{C}$ ) with a significant hyperchromic effect can be seen on heating such samples. Figure 1 shows typical transition of duplexes 0a and IIa in the presence of one equivalent of $\mathrm{Zn}^{2+}$ ion. Type II duplexes are clearly formed at low temperature. As a comparison a mismatch duplex (0b, Table 2) was checked and failed to show a melting transition. Type 0 duplexes showed expected Tm values both in metal free buffer or with added metal ions with slight variations around $29.0^{\circ} \mathrm{C}$. The Tm of type I duplexes (one strand with one Tpy moiety) are rather insensitive to metal addition. A slight contribution of the terpyridine to the stability of the duplexes was detected even in metal free buffer. Such a behaviour as already been reported [12]. Thus the specific behaviour of type II duplexes is related to the presence of the two Tpy moieties at both $3^{\prime}$ and $5^{\prime}$ ends of one strand. Extension of the link between the two conjugated Tpy by intercalation of one or two unpaired T nucleobase did not result in a different behaviour (compare data IIa to IIb and IIc in Table 2). In order to take into account the potential effect of dangling nucleotides of the target strand 1, when hybridized to its complementary oligomer, we studied various duplexes including a shorter target strand allowing the formation of blunt ends duplexes (Strand 2, Table1). As revealed in Table 2, these new duplexes (0c, Ic,d, IId,e,f) exhibited very similar behaviour to the one observed for duplexes Ia through IIc (Table 2). Type II duplexes, always revealed Tm between 10 to $20^{\circ} \mathrm{C}$. Thus dangling ends of the target cannot be responsible for these specific Tm drops.

Metalation of the bis-Tpy strand 7, 8 or 9 is associated with the drop in Tm values. This suggested to us that the link between the two Tpy units through metal complexation was involved in this behaviour. We then added excess of metal species in order to promote the formation of mono-metalated entities and thus disrupt the coordination link between the two nearby Tpy. Such a goal can be easily achieved through slight excess of $\mathrm{Ni}^{2+}$ ions or larger amounts of $\mathrm{Zn}^{2+}$ ions $[12,17]$. Data in Table 2 showed that $2 / 1\left(\mathrm{Ni}^{2+} /\right.$ duplex $)$ ratio or 20/1 
$\left(\mathrm{Zn}^{2+} /\right.$ duplex) led to significant increase in Tm values of duplexes IIa to IIf ( 28.3 to $42.4{ }^{\circ} \mathrm{C}$ ) in comparison with $1 / 1$ metal to duplex mixture $\left(<20^{\circ} \mathrm{C}\right)$. Even in large excess, $\mathrm{Fe}^{2+}$ ions failed to promote the formation of mono-metalated Tpy as predicted from thermodynamics and kinetics data $[11,17]$.

We extended this study to RNA targets and 2'-O-methyl ligands. Data are gathered in Table 3. As expected for such strands combinations we observed a raise in Tm values compared to those of similar duplexes in Table 2. Thus the unmodified 0r duplex exhibited a melting temperature of $40.4^{\circ} \mathrm{C}, 11.5^{\circ} \mathrm{C}$ higher than that of the corresponding duplex 0a. Type II duplexes exhibited cooperative melting transitions allowing the determination of $\mathrm{Tm}$ in this case. However we always noticed a drop in $\mathrm{Tm}$ of these duplexes (close to $10^{\circ} \mathrm{C}$ ) compared to those of type 0 and I duplexes upon addition of 1 equivalent of metal ion. (Table 3, columns 4 and 5). Slight excess of $\mathrm{Ni}^{2+}$ ion (2/1 metal/duplex) led also to an increase in $\mathrm{Tm}$ revealing the disruption of the coordination link between the two Tpy moieties (column 7). A noticeable difference between DNA and RNA strands was that extension of the link between the Tpy units allowed in this last case an increase in Tm. Insertion of one or two unpaired T nucleobases in the target strand also increased $\mathrm{Tm}$ from 29.9 to $37.3^{\circ} \mathrm{C}$ (Table 3, duplexes IIrb and IIrc, columns 4,5). An interesting observation was linked to the addition of $\mathrm{Mg}^{2+}$ ions on type IIr duplexes. In these cases Tm values observed for bis-Tpy-modified oligomers reached and in some cases exceeded those determined for the unmodified duplex 0r (Table 3, column 8,9). Thus, the duplex IIrc composed of the RNA strand 1r and the extended 2'-O-methyl (9m), melted at $46.6^{\circ} \mathrm{C}, 4.8^{\circ} \mathrm{C}$ higher than the corresponding unmodified duplex $\operatorname{Ir}\left(41.8^{\circ} \mathrm{C}\right)$ in the same experimental condition (see Table 3, column 9). At physiologically relevant $\mathrm{Mg}^{2+}$ concentration $(3 \mathrm{mM})$, the increase of $\mathrm{Tm}$ is $2.4^{\circ} \mathrm{C}$ (Table 3 , column 8 ). 
Mass spectral analysis.

The stoichiometry of various metal complexes was studied using mass spectrometry. Prior to mass spectral measurements, single-stranded or double-stranded oligomers were metalated using the same experimental conditions as the one used for thermal denaturation experiments i.e concentration, buffer, $\mathrm{pH}$ (see experimental protocols). An aliquot was then sampled and the buffer was exchanged for ammonium acetate.

Data for MS analysis are gathered in Table 4. The mono-Tpy conjugated strands 5 was analysed first by MALDI-Q-TOF MS. Before metalation, a mono-isotopic peak at m/z 3361.75 was observed (Calcd. for [M-H]', 3361.75). After metalation with $\mathrm{Fe}(\mathrm{II})$ ions, at a ratio of $1 / 1$ metal to oligomer, the formation of a 2/1 complex between 5 and $\mathrm{Fe}(\mathrm{II})$ was demonstrated through the presence of peaks at $\mathrm{m} / \mathrm{z} 6778.27$ (Calcd. for $[2 \mathrm{M}+\mathrm{Fe}-3 \mathrm{H}]$, 6778.34) and $\mathrm{m} / \mathrm{z}$ 3388.60 (major peak of the spectrum, calcd. for $[2 \mathrm{M}+\mathrm{Fe}-4 \mathrm{H}]^{2-}, 3388.67$ ). Similar results were observed for strands $\mathbf{5 m}$ (the corresponding 2'-O-methyl derivative of 5) with detection of peaks at $\mathrm{m} / \mathrm{z} 7318.55$ and 3658.79 corresponding to the $[2 \mathrm{M}+\mathrm{Fe} 3 \mathrm{H}]^{-}$and $[2 \mathrm{M}+\mathrm{Fe}-4 \mathrm{H}]^{2-}$ species respectively (calcd. for $\left.[2 \mathrm{M}+\mathrm{Fe}-3 \mathrm{H}]^{-}, 7318.61\right)$.

We then studied the bis-Tpy conjugates $\mathbf{7}$ and $\mathbf{7 m}$. As expected the non-metalated species were characterized by mono-isotopic peaks at m/z 3944.95 (Calcd. for [M-H]', 3944.98) and at m/z 4215.09 (Calcd. for [M-H]', 4215.07). Metal complexation was then performed by incubation of single-stranded species with $\mathrm{Fe}^{2+}$ ions at ratio of $1 / 1$ to $2 / 1$ metal to strands. The same results were obtained for these 2 stoichiometric conditions. The spectrum is shown in Figure 2. A mono-isotopic peak at m/z 3998.91 was observed for strand 7 (Calcd. 3998.89 for $[\mathrm{M}+\mathrm{Fe}-3 \mathrm{H}]^{-}$) and m/z 4268.99 (Calcd. 4268.98 for $[\mathrm{M}+\mathrm{Fe}-3 \mathrm{H}]^{-}$) for strand $\mathbf{7 m}$. We thus only revealed the 1/1 complex between bis-Tpy conjugated strands and $\mathrm{Fe}^{2+}$ ions. In order to check 
for the presence of higher oligomeric species the same experiment was performed using MALDI-TOF MS which allow higher m/z analysis (up to 10000 ). $\mathrm{Fe}^{2+}$ or $\mathrm{Zn}^{2+}$ ions were added to strand 7 at ratio of 2/1 (metal/strand). 1/1 complex were characterized in each cases at $\mathrm{m} / \mathrm{z}$ 4001.9 for $[\mathrm{M}+\mathrm{Fe}-3 \mathrm{H}]^{-}$and $\mathrm{m} / \mathrm{z} 4010.8$ for $[\mathrm{M}+\mathrm{Zn}-3 \mathrm{H}]^{-}$with calculated data of 4000.8 and 4010.4 respectively. We never observed peaks at higher $\mathrm{m} / \mathrm{z}$. However following incubation of $\mathrm{Zn}^{2+}$ ions at a ratio of $2 / 1$ metal to strand we observed a small peak at m/z 4073.4 corresponding to a bis-metallated species (Calcd.for $\left.[\mathrm{M}+2 \mathrm{Zn}-5 \mathrm{H}]^{-}, 4073.8\right)$

We have next investigated double-stranded complexes (Table 4). We chose to study the $\mathrm{Zn}^{2+}$ metalated species. For MALDI-Q-TOF MS analysis, the complex IId, were annealed in the same conditions as those used for Tm measurements (ratio 1/1, metal/duplex). The main peak at $\mathrm{m} / \mathrm{z} 2653.45$ corresponds to the target strand 2 (Calcd. for [M-H]', 2653.46). Two minor peaks were detected at $\mathrm{m} / \mathrm{z} 4006.87$ and 4068.79 corresponding to the bis-Tpy oligomers $[\mathrm{M}+\mathrm{Zn}-3 \mathrm{H}]$ and $[\mathrm{M}+2 \mathrm{Zn}-5 \mathrm{H}]$. The full complex IId was also detected as a minor peak at $\mathrm{m} / \mathrm{z}$ 6666.00 (Calcd. for $\left.\mathrm{M}_{\mathrm{III}}+\mathrm{Zn}-3 \mathrm{H}\right]$, 6666.08). The same experiment has been performed with complex IId annealed in the presence of an excess of $\mathrm{Ni}^{2+}$ ions ( $2 / 1$; metal/duplex ratio). As already observed, the main isotopic peak at $\mathrm{m} / \mathrm{z} 2653.46$ corresponds to strand $\mathbf{2}$. We noticed a clear increase in the intensity of isotopic peaks at 4000.87 and 4056.81 which corresponds to $\left[\mathrm{M}_{7}+\mathrm{Ni}-3 \mathrm{H}\right]^{-}$and $\left[\mathrm{M}_{7}+2 \mathrm{Ni}-5 \mathrm{H}\right]^{2-}$ respectively (Calcd. 4000.89 and 4056.81). Very weak peaks were detected at m/z 6659 and 6716 which correspond to the occurrence of the complexes $\left[\mathrm{M}_{\mathrm{III}}+\mathrm{Ni}-3 \mathrm{H}\right]^{-}\left[\mathrm{M}_{\mathrm{III}}+2 \mathrm{Ni}-5 \mathrm{H}\right]^{-}$(Calcd. 6659.44, 6716.11). Non-metalated species could not be detected.

\section{Gel shift analysis}

Gel shift analysis by PAGE was used to characterize the molecular species involved in 
the type II duplexes. Figure 3A shows the PAGE analysis of single strands $(\mathbf{1 r}, \mathbf{3 m}, \mathbf{5 m}, \mathbf{7 m})$ incubated in metal free conditions (EDTA completed buffer) or with $\mathrm{Fe}^{2+}$ ions before loading on the gel. Lanes 1, 2, 3 and 6 correspond to unmetalated species. 1 and 6 are respectively the target RNA strand (13 nucleotides) and the unconjugated 2'-O-methyl complementary strand (9 nucleotides). 2 and 3 correspond to the mono and bis Tpy conjugated strands. They are separated according to their molecular weight. Lane 4 and 5 shows the band shifts observed upon incubation of one equivalent of $\mathrm{Fe}^{2+}$ ions with each strand $\mathbf{7 m}$ and $\mathbf{5 m}$ respectively. The slowest moving band (lane 5) corresponds to the mono-Tpy conjugate as expected for an intermolecular complex $" \mathrm{Fe}^{2+}(\mathbf{5})_{2} "$ with a double chain length. In contrast a fast moving band (lane 4) was observed for the bis-Tpy conjugate $\mathbf{7 m}$ when metalated with $\mathrm{Fe}^{2+}$ with a mobility close to that of the unmetalated strand $\mathbf{7 m}$. Iron(II) Tpy complexes were easily detected on the same gels thanks to their highly coloured (purple) octahedral complexes (Figure 3B) were lane numbers 1', 2', 3', 4', 5', 6' correspond to the same samples as figure 3A visualized under daylight. A faint spot is observed for lane 5' apparently due to diffusion as observed for lane $\mathbf{5}$. Both the monomeric nature and the metalation of the molecular species of the spot (lane 4) were confirmed by elution and MALDI-Q-TOF analysis (m/z: 4268.99). Elution of the band on lane 5 confirmed the high molecular weight of the complex "Fe ${ }^{2+}(\mathbf{5})_{2} "(\mathrm{~m} / \mathrm{z} 7318.55$ and $\mathrm{m} / \mathrm{z}$ 3658.79). Similar results were obtained with DNA strands 1, 5, 7 (data not shown).

\section{NMR experiments.}

We report here some preliminary NMR analysis of various duplexes. We chose duplex 0a, Ia and IIa in order to carefully measure the impact of Tpy conjugates on theses doublestranded structures. Unmetalated duplexes Ia and IIa were compared to the metalated ones. 
Samples were prepared on a $0.8 \mathrm{mM}$ scale, one and two-dimensional spectra were acquired in $\mathrm{H}_{2} \mathrm{O} / \mathrm{D}_{2} \mathrm{O}(90: 10)$ with $10 \mathrm{Mm}$ phosphate buffer, $\mathrm{pH} 7,0$ at $277^{\circ} \mathrm{K}$. When needed $\mathrm{Zn}^{2+}$ ions were added stepwise until the stoichiometry of one metal for two Tpy ligands was reached. Our first analysis relies on the imino protons regions of the spectra. The imino resonances of the duplexes were assigned primarily from the imino-imino crosspeaks in the 2D NOESY spectra. Figure 4 shows the exchangeable imino region (11-15 ppm) of the one-dimensional 1H NMR spectrum for the three studied duplexes in metal freeconditions or after $\mathrm{Zn}^{2+}$ ions complexation.

Duplex 0a. Base pairs are numbered according to Figure 4. Imino protons are then numbered according to base pairs number, thus as an example, $\mathrm{G} 2 \mathrm{~N}_{1} \mathrm{H}$ and $\mathrm{T}_{4} \mathrm{~N}_{3} \mathrm{H}$ imino protons are abbreviated here as $\mathrm{G}_{2}$ and $\mathrm{T}_{4}$. All expected base pairs were detected on the duplex as deduced from the peaks found on Figure 4A. Imino-imino NOE cross-signals occured sequentially and allow the assignment of all imino protons. The imino-proton of $\mathrm{G}_{2}$ base pair which resonates at $12.09 \mathrm{ppm}$ served as a starting point for the assignment (Figure 5 ). A clear overlap was observed for $T_{3}$ and $T_{8}$. As a result of exchange with the solvent, cross-peaks of $G_{1}$ and $\mathrm{G}_{9}$ are absent in the 2D NOESY spectrum, and the resonance of these last protons exhibit a significant broadening compared to other imino peaks but are however clearly detected. Chemical shifts data are gathered in Table 5. $\left(\mathrm{G}_{1}\right.$ and $\mathrm{G}_{9}$ assignments are reversible).

Duplex Ia. In the duplex Ia, which includes a 3' Tpy ligand on the shorter strand 5 (Table 1), the guanine resonances are clearly affected and significantly broaden (Figure 4B). $\mathrm{G}_{1}, \mathrm{G}_{9}$ and $\mathrm{G}_{2}$ lines could not be assigned, exhibiting significant larger line-widths. On the opposite the central $\mathrm{G}_{6}$ resonance was not perturbated. The thymine imino region of the spectrum was also affected. The imino resonances of base pairs 3 and 4, localized in the vicinity of the Tpy conjugate, are broaden. Base pairs located at the opposite duplex end, $\mathrm{T}_{7}$ and $\mathrm{T}_{8}$ are not perturbated, $\mathrm{T}_{5}$ line being slightly broadened. As is evident in Table 5, some resonances are 
also shifted in comparison with that of duplex 0a. These variations in chemical shifts correlates with the variations in line-width. The observed upfield shifts of imino protons decrease from $\mathrm{G} 2$ to $\mathrm{T} 5$, ranging from 0.26 to $0.05 \mathrm{ppm}$.

Duplex IIa. The NMR 1D spectra of duplex IIa shows only 5 resonance lines (Figure 4C). They are all located on the 5' end of the bis-Tpy conjugated oligomer (strand 7, Table 1). Surprisingly the terminal $\mathrm{G}_{9}$ base pair is easily detected and exhibited a sharp resonance. G6 resonance line is not perturbated and exhibit similar characteristics in the three duplex (0a, Ia, IIa) both in line-width and chemical shifts (Table 5). Among the five expected lines of thymine base pairs, only 3 are detected $\left(\mathrm{T}_{5}, \mathrm{~T}_{7}, \mathrm{~T}_{8}\right) . \mathrm{T}_{5}$ and $\mathrm{T}_{7}$ are slightly broadened (compared to Ia, Figure 4B). The comparison of their chemical shifts between duplex 0a and IIa reveal also an upfield shift of resonances closed to the 5' Tpy ligand, ranging from 0.3 to $0.07 \mathrm{ppm}$. The shift regularly decrease from the 5 ' end to the core of the duplex.

We have then study the metalated duplexes Ia and IIa after addition of one $\mathrm{Zn}^{2+}$ ions for two Tpy ligands. The 1D spectra are shown in Figure 4D and 4E. We first studied the impact of metalation on the mono-Tpy conjugated duplex Ia. In these experimental conditions an intermolecular metal complex between two duplexes is expected. The observed pattern for imino resonances was closed to the one observed for the unmetalated spectra (compare Figure 4B and 4D). The main features of theses data, were the sharper resonance lines for $T_{3}, T_{4}$ and $T_{5}$ and their minor variations in chemical shifts (Table 5) compared to unmetalated duplex Ia.

The NMR imino region of the metalated duplex IIa is shown in Figure 4E. Compared to duplex IIa (Figure 4C) much more resonance lines are observed both in the guanine and the thymine imino region. This might be due to an equilibrium between two or more structures in the NMR sample. We assigned five main resonances which we supposed to belong to the major 
component of the mixture. The resonances we observed $\left(\mathrm{G}_{2}, \mathrm{~T}_{3}, \mathrm{~T}_{4}, \mathrm{~T}_{5}, \mathrm{G}_{6}\right)$ are located on the 3' end of the bis-Tpy conjugated strands, and the observed chemical shifts are closed to those observed for the unmodified duplex 0a. The metalation of duplex IIa was checked by mass spectral analysis. An aliquot of the NMR sample was submitted to MALDI-TOF (negative mode) and lead to a major peak at $\mathrm{m} / \mathrm{z} 4010.4$ (calcd. for $[\mathrm{M}+\mathrm{Zn}-3 \mathrm{H}]$, 4010.40] in full concordance with a mono metalated bis-Tpy conjugate.

\section{Discussion}

We previously demonstrated that the high affinity metal chelator Tpy [17] could be used to assemble and stabilize two complementary oligonucleotides $[12,14]$. The conjugation of Tpy moieties to stem-loop oligomers provided an efficient procedure for the cyclization of the oligomer after addition of metal ions. We report here an extension of these concepts by studying the potential of 3',5' Tpy conjugated oligonucleotides to wrap round a complementary strand when linked through metal coordination. In order to allow such a cyclization, we conceived specific linkers between the Tpy moiety and the terminal $\mathrm{OH}$ groups of oligonucleotides. These linkers were optimized through modeling. As shown in scheme 1B a one turn helical duplex will put the Tpy ligand in a face-to-face position, which when coordinated to a metal ion lead to a circularized oligonucleotide where the complementary strand passes through this circle. This topology is a prerequisite for the formation of a catenane when the target strand is also a circular oligonucleotide. In a recent paper by Göritz and Kramer a complementary approach was developed [18]. A bis-Tpy conjugated DNA strand was circularized through metal chelation, such as conformational restrictions unable double helix formation. The complementary sequences they used involved the formation of 15 base pairs 
duplex. This corresponds to a one and a half double helix turn, which put the Tpy moieties at opposite positions along the duplex. The short and non optimized arms they used for the links between 3 ' and 5 ' terminus of the bis Tpy conjugated strands will not favour the chelation of the Tpy units when hybridized to the complementary sequence.

We designed here a simplified system in order to check the conformational restrictions of such a topological object. We chose to explore the two main helical forms of nucleic acid helices by studying both B DNA duplexes and the A RNA conformation of a RNA 2'O-Me hybrid [19]. The 9-base pairs model we chose was derived from an apical loop from HCV genome. It fulfils the above criteria i.e. a length close to a one turn double-helical duplex. We have then analysed the molecular species involved in the metalated duplexes through various techniques.

Mass spectral analysis allowed us to show that the species resulting from metal addition to the bis Tpy-conjugated single strands 7 and $\mathbf{7 m}$ were a 1:1 complexes between metal and the oligomer (See Table 4). This well defined stoichiometriy could account for either a monomeric $(1+1)$ intramolecular metallo-macrocycle or oligomeric $(n+n)$ species. As we could not detected higher molecular weight entities by mass spectral analysis we tried to confirm the molecular size of the metallic complex using gel shift analysis in denaturating conditions. The mobility of the band in lane 4 (Figure 3A) is in full concordance with a low molecular monomeric compound, metalation being easily detected both by the high coloured band in Figure (lane 4, Figure 3B) and by mass spectral analysis after elution of the spot. Taken together these data lead us to conclude that $\mathbf{7}$ and $\mathbf{7 m}$ strands are fully circularized in the experimental conditions used here. Although our experimental data do not discard the simultaneous occurrence of a monocomplex terpyridine and an unmetalated one, the thermodynamic data do not favour this possibility, particularly for iron(II) complexes [17] 
Melting experiments allowed us to analyse the response of the circularized oligomer when annealed to its complementary strand. Data obtained from DNA duplexes (Table 2) underline a specific behaviour of the bis Tpy-conjugated oligomer when incubated with their target strand in the presence of metallic ions. At low temperature circularized Tpy-oligomers are paired to their targets. The observed destabilization of these duplexes (IIa) in comparison with unmodified duplexes $\mathbf{0 a}$ or mono-conjugated oligomer (Ia) is correlated with the occurrence of the coordination link between the two terminal terpyridines moieties. The released of this constraint by disruption of the link between the two Tpy (by addition of a slight excess of $\mathrm{Ni}^{2+}$ ions) is associated with a raise in melting temperature that reach those observed for unconjugated or metal-free duplexes. We thus concluded that the circularized metalated oligomer is annealed to its complementary strand. Furthermore the 2'-O-methyl circularized oligomer was able to anneal to its targeted RNA strand and reach melting temperature close to that of unmodified duplexes (Table 3). This was observed first by adding magnesium to the incubation medium. The magnesium dependence of RNA folding and RNA strand association is well documented [20, 21]. We never observed such a dependence for DNA duplexes (IIa through IIc, data not shown). When we tried to release putative conformational constraints by inclusion of unpaired nucleotides ( $\mathrm{T}$ or $\mathrm{U}$ ) at one or the both ends of strands $\mathbf{8 m}$ and $\mathbf{9 m}$, the corresponding duplexes (IIrb, IIrc) melted at higher temperatures following metal addition (Table 3, column 4 and 5). Such an effect was not observed for duplexes IIb and IIc. Additive effects are observed following magnesium addition to these extended strands. These both effects suggest that the conception and design of the link between the Tpy moieties and the oligonucleotides deserve more studies.

Duplex formation on circularized oligomer (7) was clearly shown also by NMR. Base pairs are easily detected through imino proton resonances in NMR experiments in the range 11- 
$16 \mathrm{ppm}$ [22]. As shown in Figure 4 at low temperature $\left(0^{\circ} \mathrm{C}\right)$ the duplex IIa revealed the occurrence of at least 5 imino proton lines in the range 11 to $14 \mathrm{ppm}$. It also lead us to suggest that mixtures of closely related helical conformers are formed after metal addition to duplex IIa. This observation precluded to further analyse the structure of the complex between the annealed strands by NMR. We are thus unable to conclude on the topology resulting from their association and if scheme $2 \mathrm{~B}$ provides a realistic representationof the structure.

NMR data revealed also some interesting experimental observations. According to melting temperature experiments, 3' or (and) 5' conjugation of Tpy units resulted (in the absence of metal ions) in slight increases in Tm of the corresponding duplexes (Table 2). 5' conjugation is generally more efficient in this stabilization as already observed [14]. NMR data showed an increase in the dynamic of base pairs located close to the 3 ' conjugation and on the opposite an increase in the life time of base pairs located on the 5' side. On both ends of duplex IIa an upfield shift of imino protons was observed compared to 0a. These observations suggest a different mode of interaction of Tpy with the double strand when located at the $3^{\prime}$ or $5^{\prime}$ end, correlating with differences in the stabilization abilities of these conjugates. Although the upfield shifts of imino protons following conjugation of Tpy suggest an intercalative mode of binding [23], we never noticed clear stabilizing properties of free Tpy ligands for doublestranded DNA [12]. A partial dynamic intercalation of the unmetalated Tpy could account for the observed dynamic of $3^{\prime}$ base pairs. A 5' stacking of the 5' Tpy on the last base pair could contribute to the sharper resonance observed for imino proton G9 on the duplex IIa. However an interaction of both Tpy within the minor or major groves could also not be excluded [24]. Only a complete structural analysis of such a duplex will allow a more comprehensive understanding of these experimental data.

In conclusion, in this report we have shown that a short synthetic single stranded 
oligonucleotide bearing terminal terpyridines is easily cyclized through metalation. It can be used to target DNA or RNA strands. Our study underline that the link between the Tpy moieties and the $3{ }^{\prime}, 5^{\prime}$ ends of oligomers have to be carefully designed to allow a thermodynamically favorable association between strands after metalation. More studies have to be conducted to design new links according both the nature of the targeted strand and the chemistry of the synthetic circular strand. In this last objective, 2'-O-methylated RNA seems to be the most promising approach to design efficient circularligands for RNA.

\section{Experimental Part}

Oligonucleotides synthesis

Unmodified oligonucleotides were purchased from Eurogentec. All modified oligonucleotides were synthesized on a $0.2 \mu \mathrm{mol}$ scale on a Millipore expedite 8909 DNA synthesizer using conventional ß-cyano-ethyl phosphoramidite chemistry. The modified and standard bases were dissolved in anhydrous acetonitrile $(0.1 \mathrm{M}$ final concentration). The modified phosporamidites were coupled manually with a coupling time of $15 \mathrm{~min}$. The coupling efficiency was the same as that of unmodified amidites. All oligomers were synthesized "trityl off". Standard deprotection procedures were used according to DNA and RNA sequences. The crude oligonucleotides were purified by electrophoresis on denaturating (20\%) poyacrylamide gels. The pure sample were desalted through reverse-phase maxi-clean cartridges $(\mathrm{C} 18$, Altech).

\section{$U V$ thermal melting experiments}

Purified oligonucleotides (each strand $1 \mu \mathrm{M}$ ) were diluted in $0.5 \mathrm{ml}$ of the appropriate buffer : $10 \mathrm{mM}$ phosphate buffer $(\mathrm{pH}$ 7) $150 \mathrm{mM} \mathrm{NaCl}, 100 \mu \mathrm{M}$ EDTA for metal free 
experiments. Other experiments were performed with the same buffer without EDTA. Metal addition was carried out by adding aliquots of the metal salt solution. The mixtures were boiled for $2 \mathrm{~min}$ and the hybridization was assured by a low-temperature cooling of the sample. Melting experiments were performed with a Cary $1 \mathrm{E}$ UV/Vis spectrophotometer with a temperature controller units. Samples were kept at $4^{\circ} \mathrm{C}$ for at least $30 \mathrm{~min}$ and then heated from 4 to $90^{\circ} \mathrm{C}$ at a rate of $0.4^{\circ} \mathrm{C} / \mathrm{min}$. The absorbance at $260 \mathrm{~nm}$ was measured every $30 \mathrm{~s}$. The melting temperature was determined using graphical methods [4] and reported data are the mean from at least three experiments.

Mass spectral analysis.

MALDI-Q-TOF mass spectrometry were performed on a Waters Ultima spectrometer for negative-ion detection using reference oligonucleotides for mass calibration allowing a mass accuracy better than $0.01 \mathrm{Da}$. A special preparation technique was designed to analyse Tpymodified oligonucleotides. the stainless-steel target was first covered with a thin layer of matrix [0.5 $\mu \mathrm{l}$ of 2,4,6-trihydroxyacetophenone (THAP) $10 \mathrm{mg} / \mathrm{ml}$ in acetone] and this layer was washed with standard EDTA solution $(2 \times 1 \mu \mathrm{l})$ and water $(2 \times 1 \mu \mathrm{l})$. The oligonucleotides $(0.8$ $\mu \mathrm{l}$ of $20 \mu \mathrm{M}$ solutions in water) were then deposited on this matrix layer and allowed to dry. The final preparation step was the application of a second layer of matrix [0.8 $\mathrm{ml}$ of a $4: 1$ solution of THAP $(10 \mathrm{mg} / \mathrm{ml}$ in ethanol $)$ and $100 \mathrm{mM}$ aqueous ammonium citrate $]$ and drying at room temperature.

MALDI-TOF measurements were performed with a Bruker Reflex III instrument. The same sample preparation as mentioned above was used for all Tpy-conjugated oligonucleotides. 
The gel shift analysis were performed in denaturating $20 \%$ polyacrylamide using tris buffer $\mathrm{pH}$ 8.4. The electrophoresis was carried out at 200 or $150 \mathrm{~V}$ at $4^{\circ} \mathrm{C}$. Gels bands were revealed by UV-shadow, or visualized by day-light for highly coloured terpyridine iron complexes.

\section{NMR spectroscopy.}

NMR experiments were performed on a $500 \mathrm{MHz}$ Bruker Avance spectrometer with a zgradient TXI probe. Samples were prepared on a $0.8 \mathrm{mM}$ scale, one and two-dimensional spectra were acquired in $\mathrm{H}_{2} \mathrm{O} / \mathrm{D}_{2} \mathrm{O}(90: 10)$. The $\mathrm{pH}$ of all the solutions was set to 7.0 with a 10 $\mathrm{mM}$ sodium phosphate buffer. When needed $\mathrm{Zn}^{2+}$ ions were added stepwise until the stoichiometry of 1:2 (metal/Tpy) was reached. The 1D and 2D spectra were recorded at 273K. The 2D spectra of the imino region were performed with $300 \mathrm{~ms}$ mixing times. A combination of Watergate and Jump and Return sequences was used for water suppression [25]. Proton chemical shifts were calibrated against TSP (trimethylsilylpropionic acid). All spectra were collected in a phase sensitive mode via STATES-TPPI method and processed according, by using TOPSPIN software.

\section{Structure calculations}

Energy minimization was used to optimize the Tpy-modified oligomer for wrapping the Tpymodified oligomer ligand round the targeted strand. The structure calculations were performed on a Silicon Graphics Fuel workstation using the DISCOVER module of INSIGHTII program (Accelrys), applying CVFF forcefield. The initial complex was build using ideal A-form double helical model. the Tpy metallic coordination was constrained using literature data [16]. 


\section{References}

[1] R. T. Batey, R. P. Rambo, J. A. Doudna, Angew. Chem. Int. Ed. 1999, 38, 2327

[2] J. J. Toulmé, C. Di Primo, S. Moreau, Prog. Nucleic Acid Res. Mol. Biol. 2001, 69, 1

[3] P. Svoboda, A. D. Cara, Cell Mol. Life Sci. 2006, 63, 901

[4] J. L. Mergny, L. Lacroix, Oligonucleotides 2003, 13, 515

[5] C. Dietrich-Buchecker, J. Sauvage, Chem. Rev. 1987, 87, 795

[6] F. Vögtle, T. Dünnwald, T. Schmidt, Acc. Chem. Res 1996, 29, 451

[7] G. R. Newkome, T. J. Cho, C. N. Moorefield, P. P. Mohapatra, L. A. Godinez, Chem. Eur. J. 2004, 10, 1493

[8] H. Hofmeier, R. Hoogenboom, M. E. Wouters, U. S. Schubert, J. Am. Chem. Soc. 2005, 127,2913

[9] J. Sauvage, J. Collin, J. Chambron, S. Gillerez, C. Coudret, Chem. Rev. 1994, 94, 993

[10] J. M. Berg, Y. Shi, Science 1996, 271, 1081

[11] R. Hogg, R. Wilkins, J. Chem. Soc. 1962, , 341

[12] L. Zapata, K. Bathany, J. M. Schmitter, S. Moreau, Eur. J. Org. Chem. 2003, 6, 1022

[13] A. V. Pisarev, N. E. Shirokikh, C. U. Hellen, C. R. Biol. 2005, 328, 589

[14] F. Freville, N. Pierre, S. Moreau, Can. J. Chem. 2006, 84, 854

[15] N. N. Dioubankova, A. D. Malakhov, D. A. Stetsenko, V. A. Korshun, M. J. Gait, Org. Lett. 2002, 4, 4607

[16] A. T. Baker, H. A. Goodwin, Aust. J. Chem. 1985, 38, 207

[17] R. Holyer, C. Hubbard, S. Kettle, R. Wilkins, Inorg. Chem. 1966, 5, 622

[18] M. Goritz, R. Kramer, J. Am. Chem. Soc. 2005, 127, 18016 
[19] M. Egli, Angew. Chem. Int. Ed. 1996, 35, 1894

[20] D. Lilley, Biopolymers 1998, 48, 101

[21] P. B. Moore, Annu. Rev. Biochem. 1999, 68, 287

[22] D. Wemmer, in 'Nucleic Acids, Structures, Properties And Functions', Ed. V. Bloomfield, D. Crothers, I. Tinoco, Sausalito, 1999, , p.111

[23] J. Feigon, W. A. Denny, W. Leupin, D. R. Kearns, J. Med. Chem. 1984, 27, 450

[24] W. D. Wilson, F. A. Tanious, R. A. Watson, H. J. Barton, A. Strekowska, D. B. Harden, L. Strekowski, Biochemistry 1989, 28, 1984

[25] D. Collin, C. Heijenoort, C. Boiziau, J. Toulme, E. Guittet, Nucleic Acids Res. 2000, 28, 3386 
Table 1

\begin{tabular}{|c|c|c|c|c|c|c|c|c|c|c|c|c|c|c|c|c|c|c|}
\hline $\begin{array}{l}\text { Strand } \\
\text { number }\end{array}$ & & & & & & & & & & & & & & & & & $\begin{array}{l}\text { Calcd. } \\
\text { Isotopic } \\
\text { Mass }\end{array}$ & $\begin{array}{l}\text { Exp. } \\
{[\mathrm{M}-\mathrm{H}]^{-}}\end{array}$ \\
\hline 1 & $5^{\prime}$ & $\mathrm{G}$ & $G$ & $\mathrm{~T}$ & $\mathrm{C}$ & $\mathrm{C}$ & $\mathrm{T}$ & $\mathrm{T}$ & $\mathrm{T}$ & $C$ & $\mathrm{~T}$ & $\mathrm{~T}$ & $G$ & $G$ & & 31 & & \\
\hline $1 r$ & $5^{\prime}$ & $G$ & $G$ & $\bar{U}$ & $\mathrm{C}$ & $\mathrm{C}$ & $\mathrm{U}$ & $\bar{U}$ & $\mathrm{U}$ & $C$ & $U$ & $\mathrm{U}$ & $G$ & $G$ & & $3^{\prime}$ & & \\
\hline 2 & $5^{\prime}$ & & & & $C$ & $C$ & $\mathrm{~T}$ & $\mathrm{~T}$ & $\mathrm{~T}$ & $C$ & $\mathrm{~T}$ & $\mathrm{~T}$ & $G$ & & & $3^{\prime}$ & & \\
\hline $2 r$ & $5^{\prime}$ & & & & $C$ & $C$ & $\mathrm{U}$ & $\mathrm{U}$ & $\mathrm{U}$ & $C$ & $\mathrm{U}$ & $\mathrm{U}$ & $G$ & & & 31 & & \\
\hline 3 & $5^{\prime}$ & & & & $C$ & $A$ & $A$ & $\bar{G}$ & $A$ & $\mathrm{~A}$ & $A$ & $\mathrm{G}$ & $G$ & & & 31 & & \\
\hline $3 m$ & $5^{\prime}$ & & & & $C$ & $A$ & $A$ & $\bar{G}$ & $A$ & $A$ & $A$ & $\mathrm{G}$ & $G$ & & & 31 & & \\
\hline 4 & $5^{\prime}$ & & & & $C$ & $A$ & $A$ & $A$ & $A$ & $\mathrm{~A}$ & $\mathrm{~A}$ & $G$ & $G$ & & & 31 & & \\
\hline 5 & $5^{\prime}$ & & & & $\mathrm{C}$ & $A$ & $A$ & $\mathrm{G}$ & $A$ & $A$ & $A$ & $\mathrm{G}$ & G & $P$ & & 31 & 3362.76 & 3361.75 \\
\hline $5 m$ & $5^{\prime}$ & & & & $C$ & $A$ & $A$ & $\bar{G}$ & $A$ & $A$ & $\mathrm{~A}$ & $\mathrm{G}$ & $G$ & $P$ & & 31 & 3632.85 & 3631.84 \\
\hline 6 & $5^{\prime}$ & & & $P$ & $C$ & $A$ & $A$ & $\mathrm{G}$ & $A$ & $\mathrm{~A}$ & $\mathrm{~A}$ & $\mathrm{G}$ & $G$ & & & 31 & 3362.76 & 3361.75 \\
\hline 7 & $5^{\prime}$ & & & $P$ & $C$ & $A$ & $A$ & $\mathrm{G}$ & $A$ & $A$ & $A$ & $\mathrm{G}$ & $G$ & $P$ & & $3^{\prime}$ & 3945.98 & 3944.95 \\
\hline $7 m$ & $5^{\prime}$ & & & $P$ & $C$ & $A$ & $A$ & $\mathrm{G}$ & $A$ & $\mathrm{~A}$ & $\mathrm{~A}$ & $\mathrm{G}$ & $G$ & $P$ & & 31 & 4216.07 & 4215.06 \\
\hline 8 & $5^{\prime}$ & & & $P$ & $C$ & $A$ & $A$ & $\bar{G}$ & $A$ & $A$ & $A$ & $\mathrm{G}$ & $G$ & $\mathrm{~T}$ & $P$ & 31 & 4250.02 & 4249.00 \\
\hline $8 m$ & $5^{\prime}$ & & & $P$ & $C$ & $A$ & $A$ & $G$ & $A$ & $A$ & $A$ & $\mathrm{G}$ & $\mathrm{G}$ & $U$ & $\mathrm{P}$ & 31 & 4536.11 & 4535.09 \\
\hline 9 & $5^{\prime}$ & & $P$ & $\mathrm{~T}$ & $C$ & $A$ & $A$ & $\mathrm{G}$ & $A$ & $A$ & $\mathrm{~A}$ & $\mathrm{G}$ & $G$ & $\mathrm{~T}$ & $P$ & 31 & 4554.07 & 4553.04 \\
\hline $9 m$ & $5^{\prime}$ & & $P$ & $\mathrm{~T}$ & $C$ & $A$ & $A$ & $\bar{G}$ & $A$ & $A$ & $A$ & $\mathrm{G}$ & $G$ & $\mathrm{~T}$ & $P$ & 31 & 4824.16 & 4823.21 \\
\hline
\end{tabular}

Table 2

\begin{tabular}{|l|l|c|c|c|c|c|c|c|}
\hline Duplexes & Strands & $\begin{array}{c}\text { Metal free } \\
\text { buffer }\end{array}$ & $\begin{array}{c}\mathrm{Zn}^{2+} \\
1 \text { eq. }\end{array}$ & $\begin{array}{c}\mathrm{Fe}^{2+} \\
\text { leq. }\end{array}$ & $\begin{array}{c}\mathrm{Ni}^{2+} \\
\text { leq. }\end{array}$ & $\begin{array}{c}\mathrm{Zn}^{2+} \\
20 \text { eq. }\end{array}$ & $\begin{array}{c}\mathrm{Fe}^{2+} \\
100 \text { eq. }\end{array}$ & $\begin{array}{c}\mathrm{Ni}^{2+} \\
2 \text { eq. }\end{array}$ \\
\hline Oa & 1,3 & 28.9 & 28.3 & 29.5 & nd & & & \\
\hline Ob & 1,4 & $\mathrm{n}$ & $\mathrm{n}$ & & & & & \\
\hline Ia & 1,5 & 31.2 & 31.6 & 32.3 & & & & \\
\hline Ib & 1,6 & 33.5 & 34.6 & 35.0 & & & & \\
\hline Ila & 1,7 & 35.1 & $10 \sim 20$ & $10 \sim 20$ & $10 \sim 20$ & 28.3 & $10 \sim 20$ & 42.4 \\
\hline Ilb & 1,8 & 35.0 & $10 \sim 20$ & $10 \sim 20$ & $10 \sim 20$ & & & \\
\hline Ilc & 1,9 & 34.2 & $10 \sim 20$ & $10 \sim 20$ & $10 \sim 20$ & & & \\
\hline Oc & 2,3 & 26.5 & 24.9 & 26.4 & & & & \\
\hline Ic & 2,5 & 29.1 & 30.4 & 29.0 & & & & \\
\hline Id & 2,6 & 33.4 & 33.6 & 32.9 & & & & \\
\hline Ild & 2,7 & 34.0 & $10 \sim 20$ & $10 \sim 20$ & & & $10 \sim 20$ & 36.4 \\
\hline Ile & 2,8 & 32.8 & $10 \sim 20$ & $10 \sim 20$ & $10 \sim 20$ & & $10 \sim 20$ & 36.6 \\
\hline IIf & 2,9 & 32.6 & $10 \sim 20$ & $10 \sim 20$ & & & $10 \sim 20$ & 36.1 \\
\hline
\end{tabular}


Table 3

\begin{tabular}{|l|l|c|c|c|c|c|c|c|}
\hline Duplexes & Strands & $\begin{array}{c}\text { Metal free } \\
\text { buffer }\end{array}$ & $\begin{array}{c}\mathrm{Zn}^{2+} \\
1 \text { eq. }\end{array}$ & $\begin{array}{c}\mathrm{Fe}^{2+} \\
\text { eq. }\end{array}$ & $\begin{array}{c}\mathrm{Ni}^{2+} \\
\text { leq. }\end{array}$ & $\begin{array}{c}. \mathrm{Ni}^{2+} \\
2 \text { eq. }\end{array}$ & $\begin{array}{c}\mathrm{Zn}^{2+}, 1 \text { eq. } \\
\mathrm{Mg}^{2+}(3 \mathrm{mM}) .\end{array}$ & $\begin{array}{c}\mathrm{Zn}^{2+}, 1 \mathrm{eq} . \\
\mathrm{Mg}^{2+}(10 \mathrm{mM})\end{array}$ \\
\hline Ora & $1 r, 3 \mathrm{~m}$ & 40.4 & 40.3 & 40.6 & & & 40.0 & 41.8 \\
\hline Ira & $1 \mathrm{r}, 5 \mathrm{~m}$ & 41.4 & 42.2 & 41.7 & & & & \\
\hline IIra & $1 \mathrm{r}, 7 \mathrm{~m}$ & 43.3 & 29.9 & 29.4 & 31.4 & 39.8 & 33.5 & 42.8 \\
\hline IIrb & $1 \mathrm{r}, 8 \mathrm{~m}$ & 44.6 & 33.2 & 36.2 & 35.0 & 43.1 & 39.0 & 44.3 \\
\hline IIrc & $1 \mathrm{r}, 9 \mathrm{~m}$ & 43.3 & 37.3 & 37.1 & 35.7 & 41.2 & 42.4 & 46.6 \\
\hline
\end{tabular}

Table 4

\begin{tabular}{|c|c|c|c|}
\hline Strand Number & Species & Calculated Data & Experimental \\
\hline 5 & {$[\mathrm{M}-\mathrm{H}]^{-}$} & 3361.75 & 3361.75 \\
\hline $5+\mathrm{Fe}$ & $\begin{array}{l}{[2 \mathrm{M}+\mathrm{Fe}-3 \mathrm{H}]^{-}} \\
{[2 \mathrm{M}+\mathrm{Fe}-4 \mathrm{H}]^{2-}}\end{array}$ & $\begin{array}{l}6778.34 \\
3388.67\end{array}$ & $\begin{array}{l}6778.27 \\
3388.60\end{array}$ \\
\hline $5 m+F e$ & $\begin{array}{l}{[2 \mathrm{M}+\mathrm{Fe}-3 \mathrm{H}]^{-}} \\
{[2 \mathrm{M}+\mathrm{Fe}-4 \mathrm{H}]^{2-}}\end{array}$ & $\begin{array}{l}7318.61 \\
3658.80\end{array}$ & $\begin{array}{l}7318.55 \\
3658.79\end{array}$ \\
\hline 7 & {$[\mathrm{M}-\mathrm{H}]^{-}$} & 3944.98 & 3944.95 \\
\hline $7+\mathrm{Fe}$ & {$[\mathrm{M}+\mathrm{Fe}-3 \mathrm{H}]^{-}$} & 3998.89 & 3998.91 \\
\hline $7 m$ & {$[\mathrm{M}-\mathrm{H}]^{-}$} & 4215.07 & 4215.09 \\
\hline $7 m+F e$ & {$[\mathrm{M}+\mathrm{Fe}-3 \mathrm{H}]^{-}$} & 4268.98 & 4268.99 \\
\hline $2+7+Z n$ & $\begin{array}{l}{\left[\mathrm{M}_{2}-\mathrm{H}\right]^{-}} \\
{\left[\mathrm{M}_{7}+\mathrm{Zn}-3 \mathrm{H}\right]^{-}} \\
{\left[\mathrm{M}_{7}+2 \mathrm{Zn}-5 \mathrm{H}\right]^{-}} \\
{\left[\mathrm{M}_{\mathrm{IId}}+\mathrm{Zn}-3 \mathrm{H}\right]^{-}} \\
{\left[\mathrm{M}_{\mathrm{IId}}+2 \mathrm{Zn}-5 \mathrm{H}\right]^{-}}\end{array}$ & $\begin{array}{l}2653.46 \\
4006.89 \\
4068.81 \\
6666.14 \\
6728.06 \\
\end{array}$ & $\begin{array}{l}2653.45 \\
4006.87 \\
4068.79 \\
6666.00 \\
6729.00 \\
\end{array}$ \\
\hline $2+7+\mathrm{Ni}$ & $\begin{array}{l}{\left[\mathrm{M}_{2}-\mathrm{H}\right]^{-}} \\
{\left[\mathrm{M}_{7}+\mathrm{Ni}-3 \mathrm{H}\right]^{-}} \\
{\left[\mathrm{M}_{7}+2 \mathrm{Ni}-5 \mathrm{H}\right]^{-}} \\
{\left[\mathrm{M}_{1 \mathrm{IId}}+\mathrm{Ni}-3 \mathrm{H}\right]^{-}} \\
{\left[\mathrm{M}_{\text {IIId }}+2 \mathrm{Ni}-5 \mathrm{H}\right]^{-}}\end{array}$ & $\begin{array}{l}2653.46 \\
4000.89 \\
4056.81 \\
6659.44 \\
6716.11\end{array}$ & $\begin{array}{l}2653.46 \\
4000.87 \\
4056.81 \\
6659.00 \\
6716.00\end{array}$ \\
\hline
\end{tabular}


Table 5

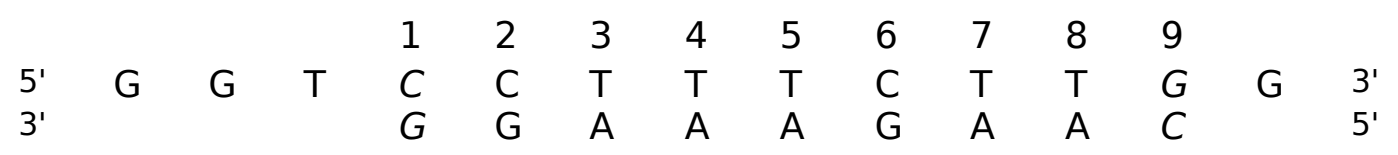

\begin{tabular}{|l|c|c|c|c|c|c|c|c|c|}
\cline { 2 - 9 } \multicolumn{1}{c|}{} & \multicolumn{9}{c|}{ Imino protons } \\
\cline { 2 - 10 } \multicolumn{1}{c|}{} & G1 & G2 & T3 & T4 & T5 & G6 & T7 & T8 & G9 \\
\hline Duplexes & & & & & & & & & \\
\hline 0a & $\begin{array}{l}12.58 \\
\text { a }\end{array}$ & 12.68 & 13.97 & 13.83 & 13.52 & 12.09 & 13.66 & 13.97 & $\begin{array}{l}12.41 \\
\text { a }\end{array}$ \\
\hline Ia & & $\begin{array}{l}12.42 \\
(0.26)\end{array}$ & $\begin{array}{l}13.82 \\
(0.15)\end{array}$ & $\begin{array}{l}13.75 \\
(0.08)\end{array}$ & $\begin{array}{l}13.47 \\
(0.05)\end{array}$ & 12.09 & 13.66 & 13.96 & \\
\hline Ila & & & & & $\begin{array}{l}13.45 \\
(0.07)\end{array}$ & $\begin{array}{l}12.09 \\
(0)\end{array}$ & $\begin{array}{l}13.57 \\
(0.1)\end{array}$ & $\begin{array}{l}13.77 \\
(0.2)\end{array}$ & $\begin{array}{l}12.11 \\
(0.3)\end{array}$ \\
\hline Ia $+\mathrm{Zn}$ & & 12.43 & 13.88 & 13.75 & 13.47 & 12.10 & 13.67 & 13.96 & \\
\hline Ila $+\mathrm{Zn}$ & & 12.61 & 13.94 & 13.77 & 13.45 & 12.08 & & & \\
\hline
\end{tabular}




\section{$\underline{\text { Legends }}$}

\section{Table 1}

Sequences of the various strands used in this study. $\mathrm{r}$ stands for ribonucleotides, $\mathrm{m}$ for 2'-O-Meribonucleotides. Mass spectral data were recorded on a Maldi-Q-TOF spectrometer (mass accuracy better than $0.01 \mathrm{Da}$, see experimental procedure)

\section{$\underline{\text { Table } 2}$}

Melting temperatures of the various DNA duplexes formed from strand association (column 2). $\mathrm{Tm}\left( \pm 1^{\circ} \mathrm{C}\right)$ are mean values of at least three experiments. Buffer : $10 \mathrm{mM}$ phosphate buffer $(\mathrm{pH}$ 7.0) $150 \mathrm{mM} \mathrm{NaCl}$. Metal free buffer was completed with $200 \mu \mathrm{M}$ EDTA. eq. refers to duplex concentration $(1 \mu \mathrm{M}), \mathrm{n}$ stands for no transition, 10 20 stands for $\mathrm{Tm}$ between 10 to $20^{\circ} \mathrm{C}$

\section{$\underline{\text { Table } 3}$}

Melting temperature of the RNA duplexes formed from the strand associations shown in column 2. Tm $\left( \pm 1^{\circ} \mathrm{C}\right)$ are mean values of at least three experiments. Buffer : $10 \mathrm{mM}$ phosphate buffer (pH 7.0) $150 \mathrm{mM} \mathrm{NaCl}$. Metal free buffer was completed with $200 \mu \mathrm{M}$ EDTA. eq. refers to duplex concentration $(1 \mu \mathrm{M})$.

\section{$\underline{\text { Table } 4}$}

Mass spectral data of oligonucleotide strands and duplexes. MALDI-Q-TOF mass spectrometry was performed on a Waters Ultima spectrometer (see experimental procedure for details on 
sample preparation). Mass accuracy better than $0.01 \mathrm{Da}$.

\section{$\underline{\text { Table } 5}$}

The chemical shifts (ppm) of the imino proton resonances in the various duplexes.

a: reversible assignments.

In parentheses $\Delta \mathrm{Tm}=\mathrm{Tm}($ duplex $0 \mathrm{a})-\mathrm{Tm}($ duplex Ia or IIa $)$

\section{Figure 1}

UV melting curves (260 nm) of duplexes 0a (links) and IIa (right). Concentration of duplexes $1 \mu \mathrm{M}$, in the presence of one equivalent of $\mathrm{Zn}^{2+}$ ions $(1 \mu \mathrm{M})$. The heating rate was $0.5^{\circ} \mathrm{C} / \mathrm{min}, . \mathrm{Y}$ axis $(\% \mathrm{H})$ is the percent of hyperchromicity.

\section{Figure 2}

MALDI-Q-TOF spectra of strand 7 after metalation with $\mathrm{Fe}^{2+}$. Inset : isotopic distribution of the main species $\left[\mathrm{M}_{7}+\mathrm{Fe}-3 \mathrm{H}\right]^{-}$

\section{Figure 3}

Denaturating $20 \%$ PAGE analysis. A) Visualization by UV shadowing. Lane 1(1r); lane 2 $(\mathbf{5 m})$; lane $3(\mathbf{7 m})$; lane $4\left(\mathbf{7 m}+\mathrm{Fe}^{2+}\right)$; lane $5\left(\mathbf{5 m}+\mathrm{Fe}^{2+}\right)$; lane $6(\mathbf{2 m})$. B) Same gel visualized under daylight. Lanes 4', 5', correspond to lanes of 4, 5, (Figure 3A). Purple coloured spot lane 4' and 5' revealed Iron II Tpy complexes.

\section{Figure 4}

One-dimensional 1H NMR spectra of the exchangeable imno region (11-15 ppm) of the various 
duplexes. 4A duplex 0a, 4B duplex Ia, 4C duplex IIa, 4D duplex Ia with one equivalent of $\mathrm{Zn}^{2+}$ ions, 4E duplex IIa with one equivalent of $\mathrm{Zn}^{2+}$ ions. Base pair numbers are indicated in the included sketch upperright. Imino protons are numbered accordingly. eq. refers to duplex concentration $(1 \mu \mathrm{M})$, $\mathrm{n}$ stands for no transition.

\section{Figure 5}

Expanded imino-imino region of the two dimensional NOESY map in 90/10 H2O/D2O for the duplex 0a. The lines illustrate the NOE walk along the imino protons. Imino proton are numbered according to base pair numbers.

\section{$\underline{\text { Scheme } 1}$}

Schematic representation of a catenane structure (A). Cyclisation of a bis(Tpy) modified oligonucleotide on a target strand upon metal chelation

\section{$\underline{\text { Scheme } 2}$}

Chemical structure of bis(Tpy) conjugated oligonucleotides (A). Optimized structure of a Aform duplex with constrained Tpy distances. (see experimental part). 
Scheme 1

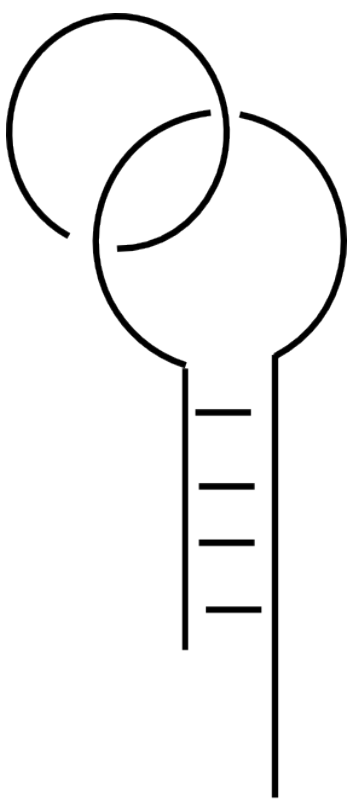

A
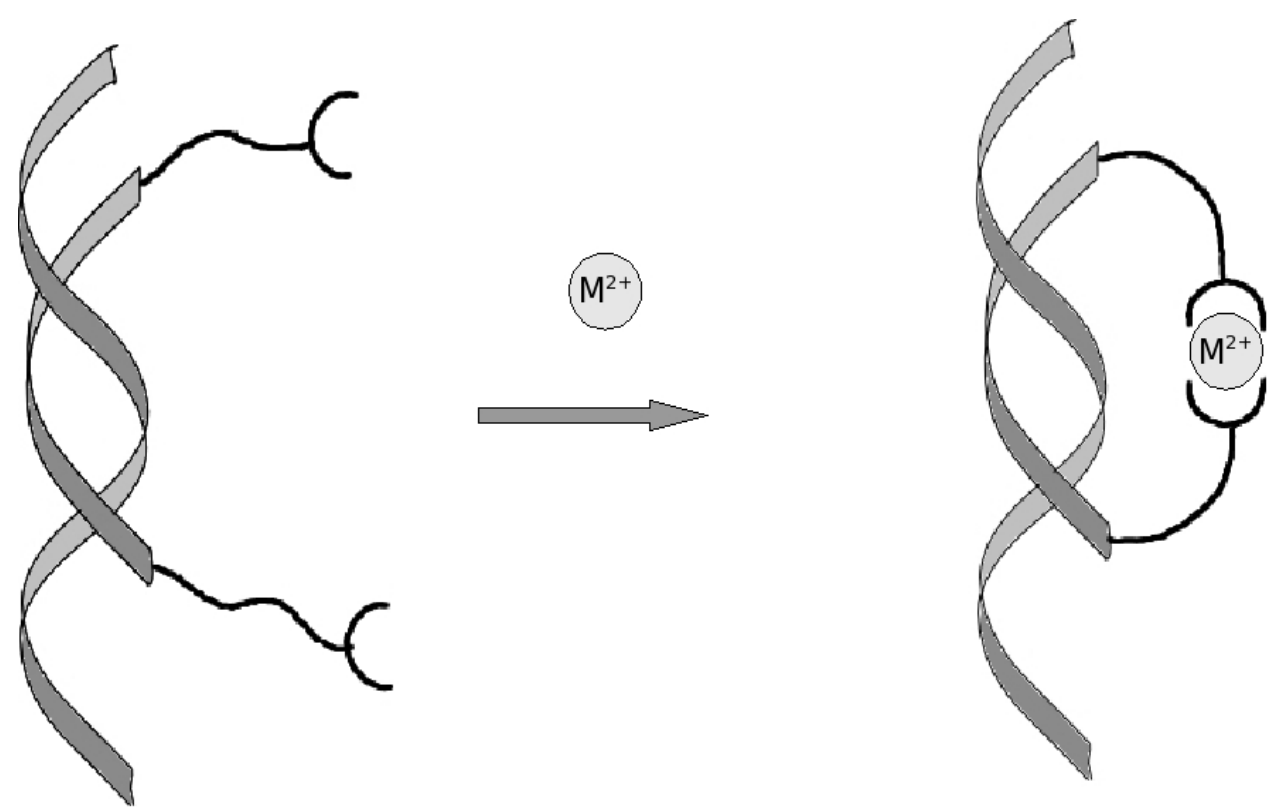
29

Scheme 2

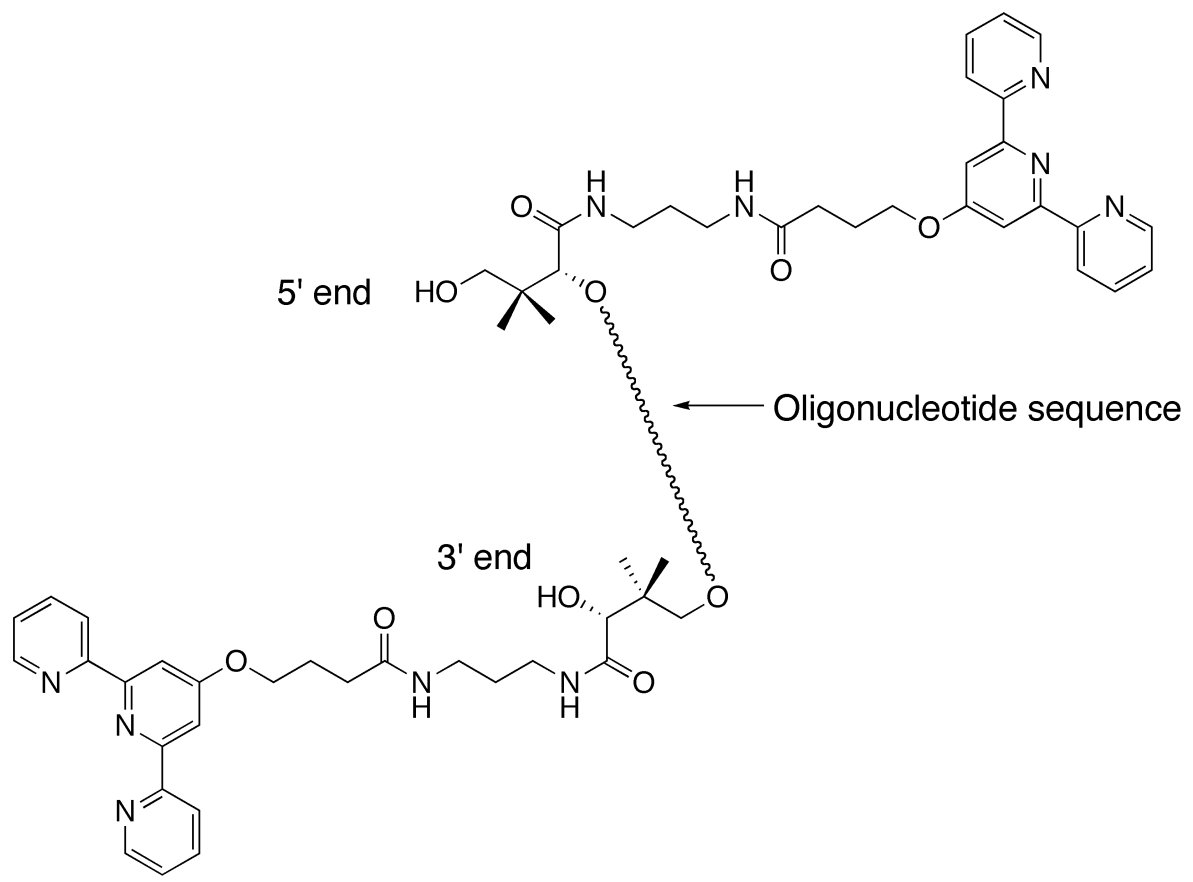

A

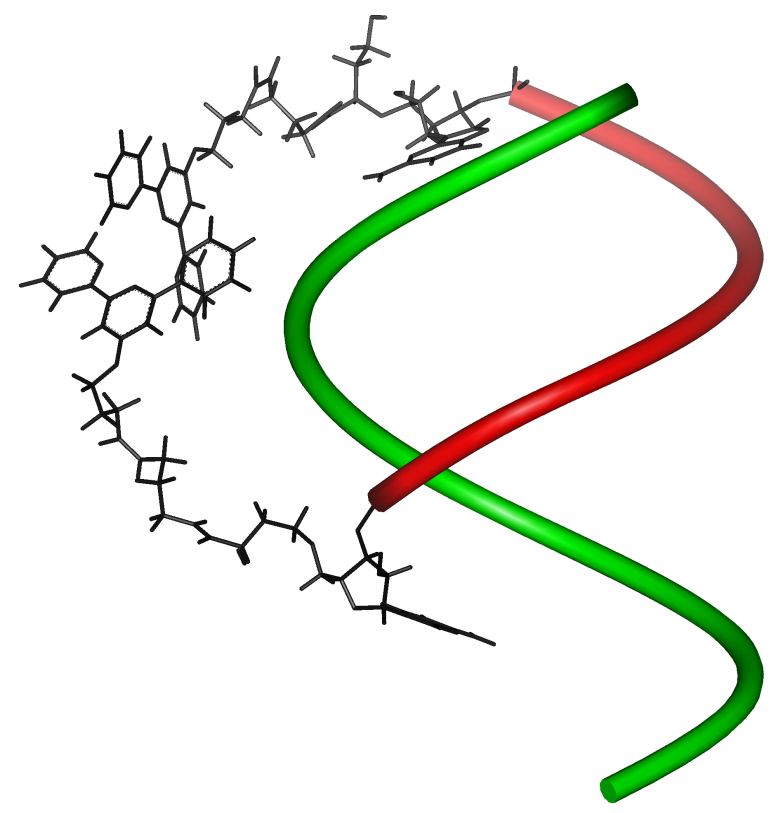

B 
Figure 1

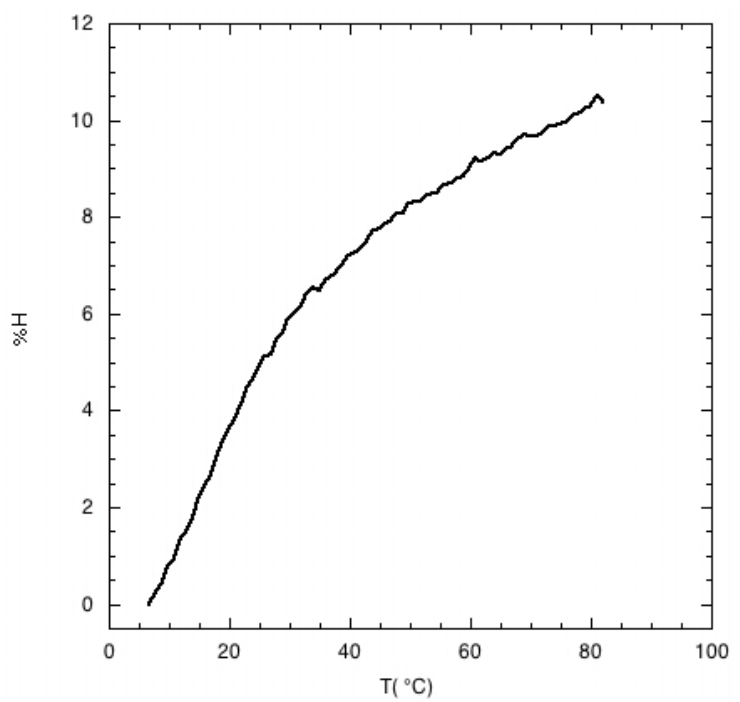

$0 \mathrm{~A}$

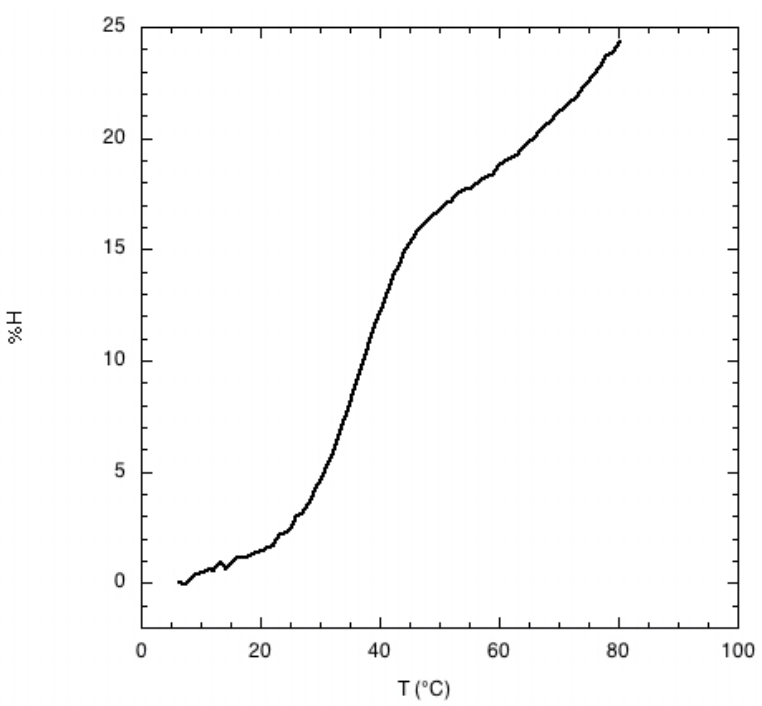

IIa

Figure 2

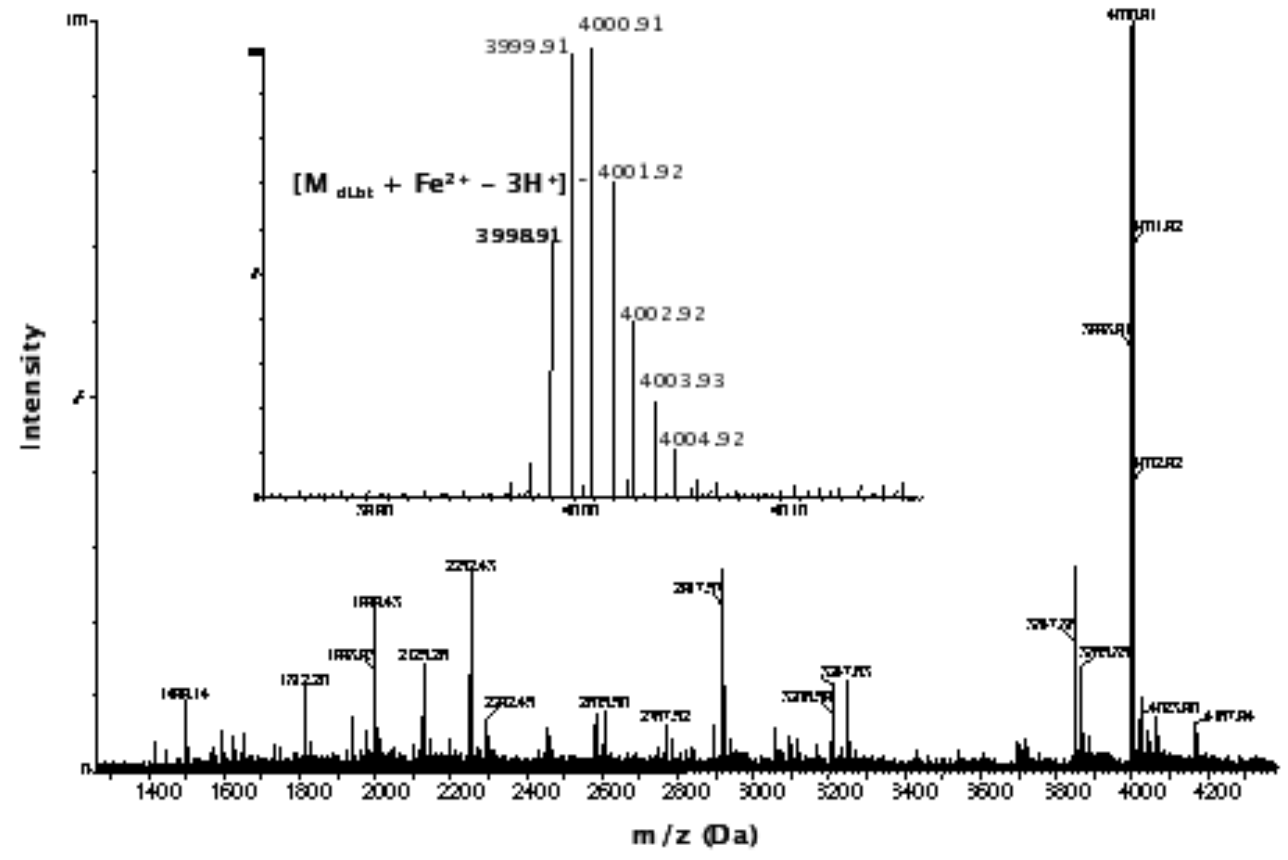


Figure 3
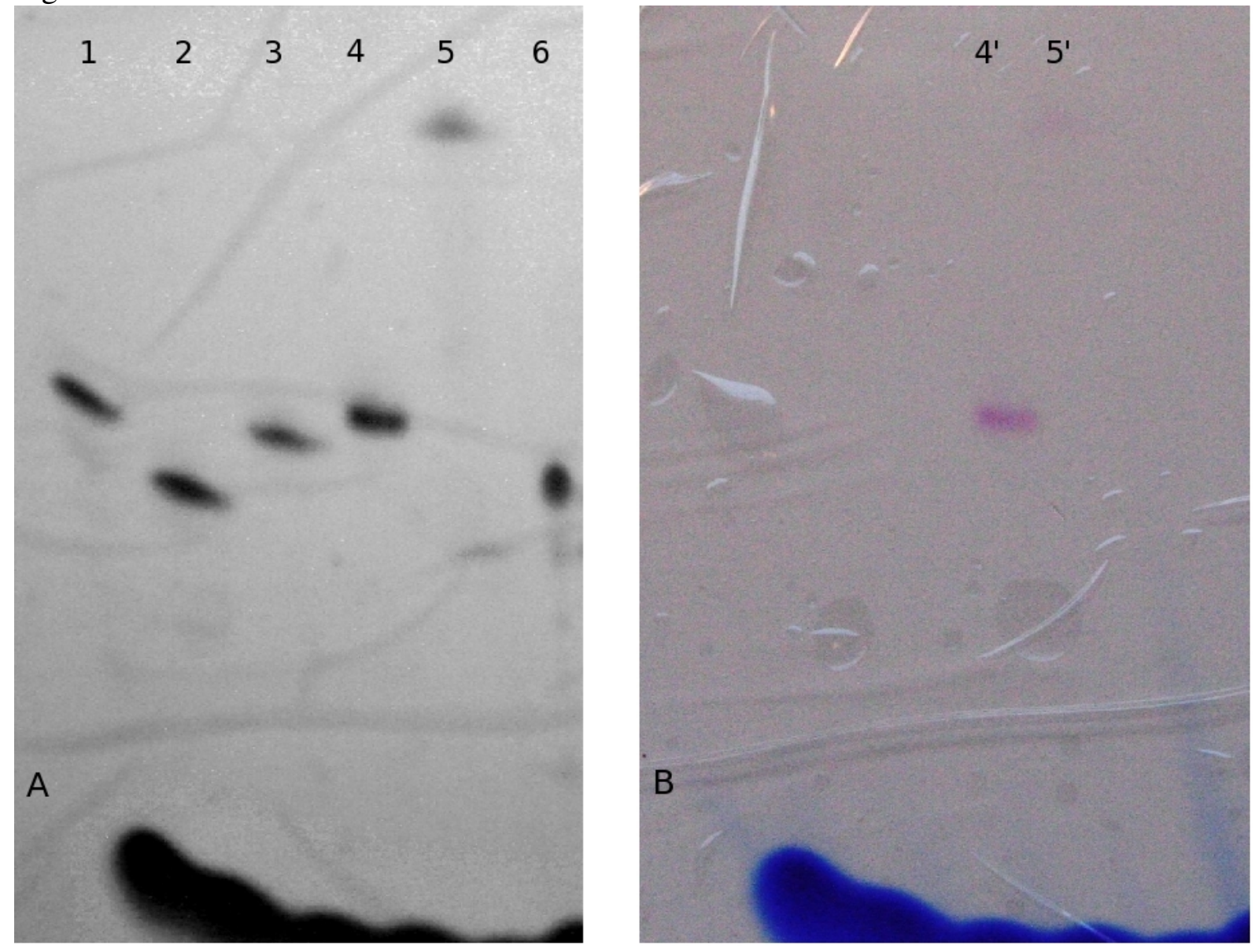
Figure 4
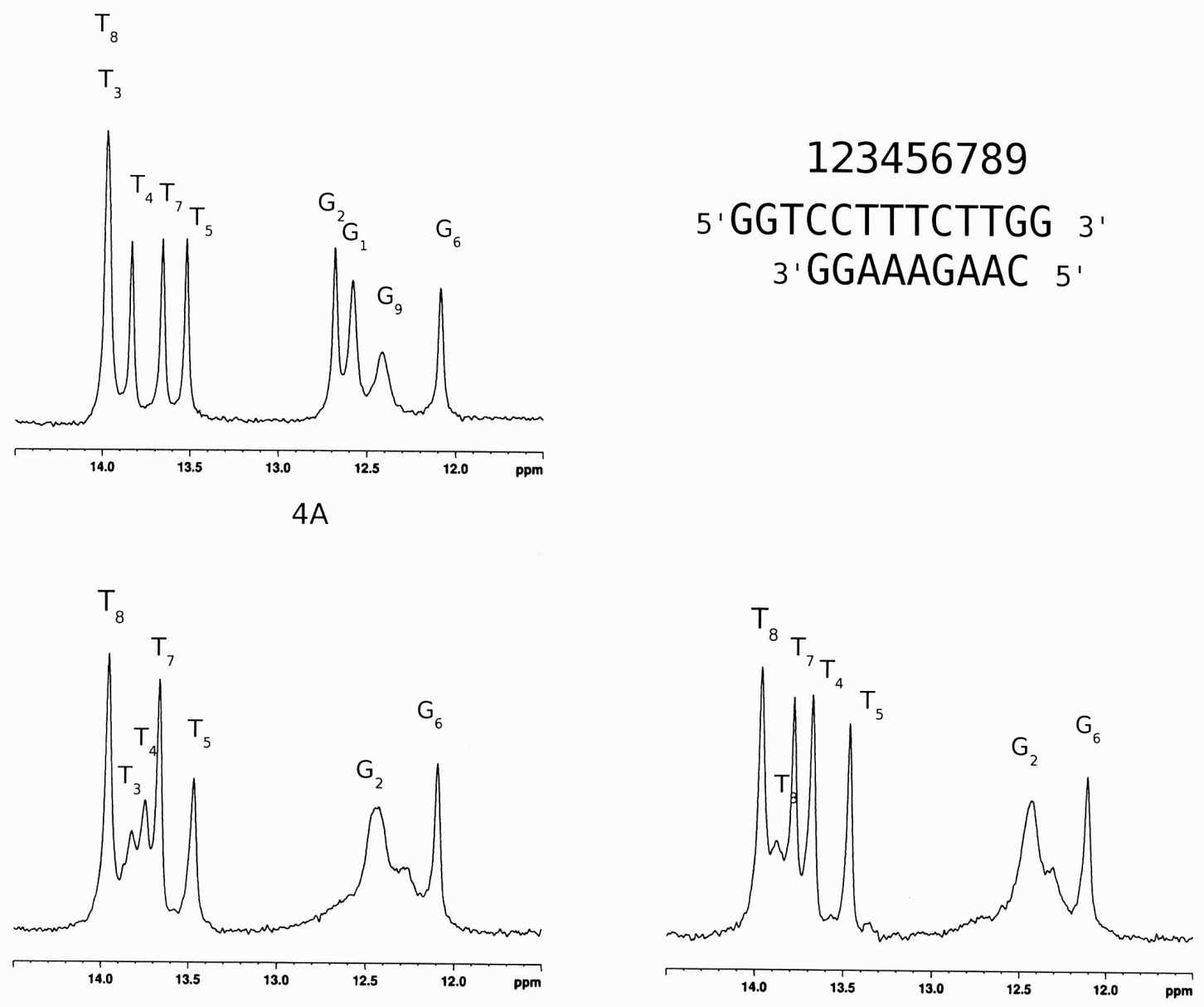

4B

4D
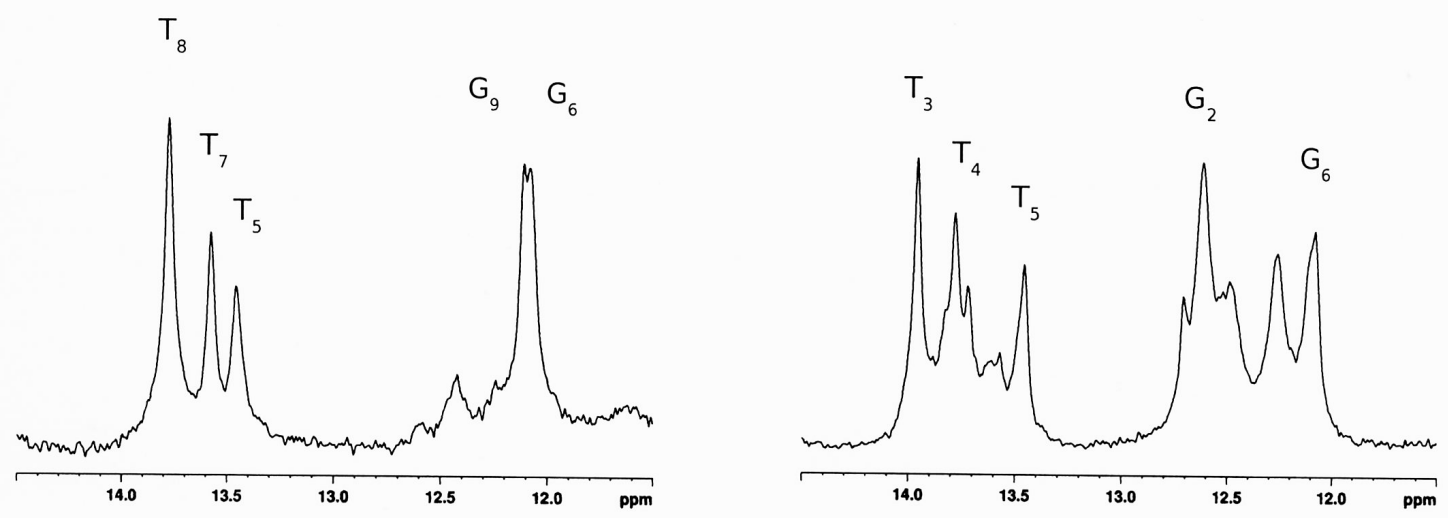

4C 

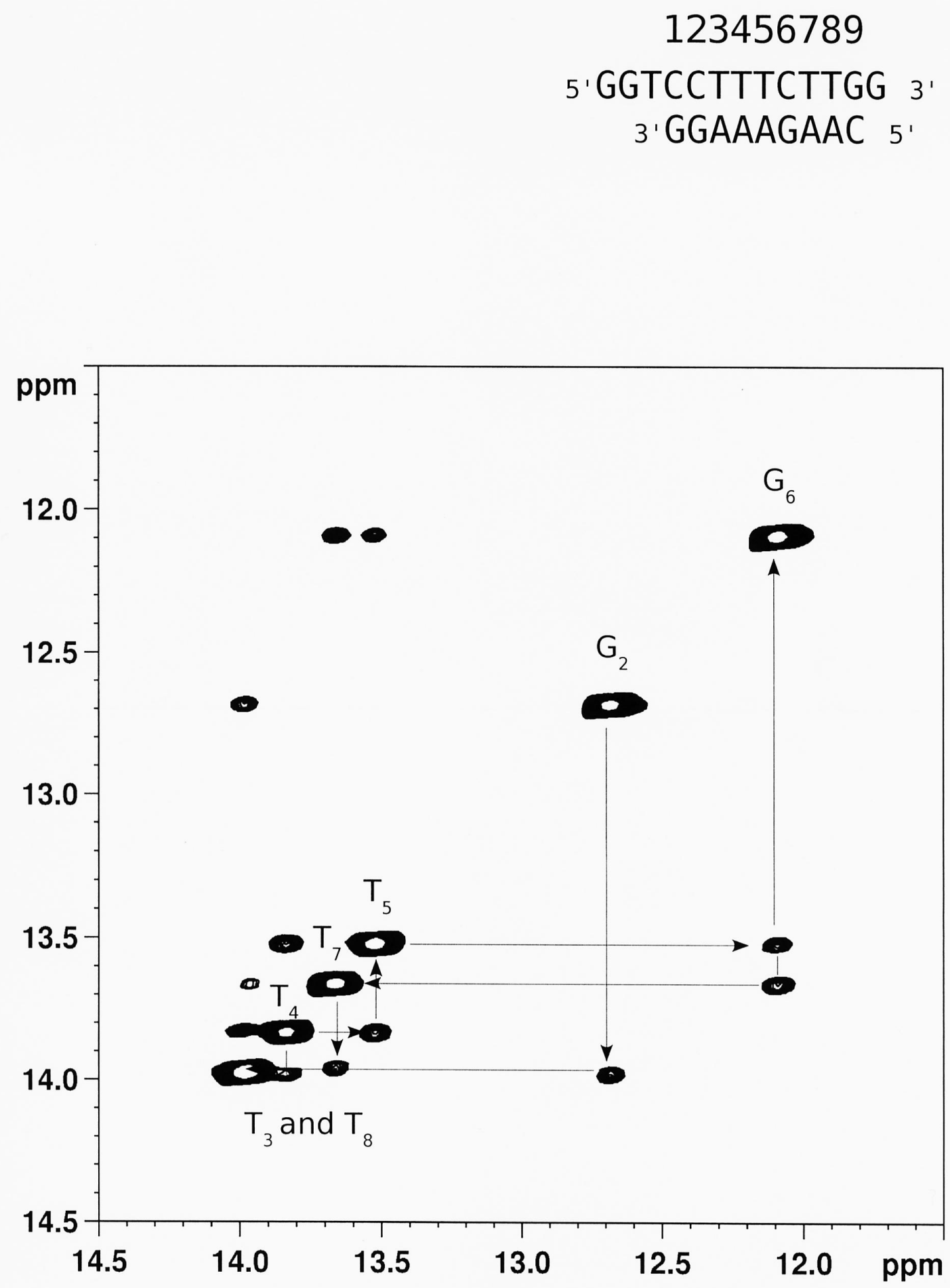


\section{Table of Contents}

Conjugation of chelating 2,2':6',2"'terpyridine moieties at both 3' and 5' ends of oligonucleotides allowed a smooth cyclization of this oligomer on its complementary target upon addition of metal ion.

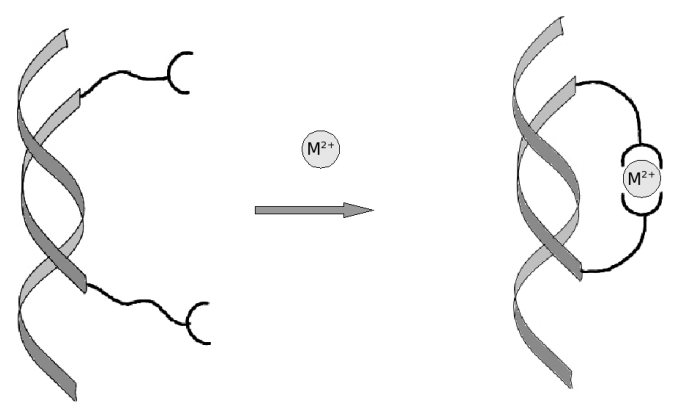

